Marquette University

e-Publications@Marquette

College of Communication Faculty Research and

Publications

Communication, College of

$1-1-2007$

\title{
Mothers of Soldiers in Wartime: A National News Narrative
}

Karen L. Slattery

Marquette University, karen.slattery@marquette.edu

Ana C. Garner

Marquette University, ana.garner@marquette.edu

Accepted version. Critical Studies in Media Communication, Vol. 24, No. 5 (2007): 429-445. DOI. (C) 2007 Taylor \& Francis (Routledge). Used with permission. 


\title{
Mothers of Soldiers in Wartime: A National News Narrative
}

\author{
Karen Slattery \\ Department of Broadcasting and Electronic Communication, \\ Marquette University \\ Milwaukee, WI
}

\author{
Ana C. Garner \\ College of Communication, Marquette University \\ Milwaukee, WI
}

\begin{abstract}
:
This study examined how the national new media represents mothers of U.S. combat soldiers in the Iraq War. Mothers of soldiers were depicted as archetypal good mothers, that is, mothers who continued their maternal work after their children were deployed. However, not all mothers were depicted as the archetypal patriotic mother, i.e., a good mother who is also stoic and silent about the war and her child's role in it. Mothers of soldiers were portrayed as good mothers who sometimes also voiced their attitudes about the war effort. The maternal attitudes ranged from complete support for the war to opposition to the war but support for the soldiers. The findings suggest a picture of wartime motherhood that is more nuanced than the historical image of the patriotic mother suggests.
\end{abstract}

Keywords: good mother, patriotic mother, combat soldiers, Iraq War, news media, maternal work.

Critical Studies in Media Communication, Vol. 24, No. 5 (2007): pg. 429-445. DOI. This article is (C) Taylor \& Francis (Routledge) and permission has been granted for this version to appear in e-Publications@Marquette. Taylor \& Francis (Routledge) does not grant permission for this article to be further copied/distributed or hosted elsewhere without the express permission from Taylor \& Francis (Routledge). 
Most news narratives about war give center stage to military performance on the battlefield and to government spokespersons (Bruck, 1989). Other actors in mediated war stories play minor roles, with the smallest parts going to victims of war (e.g., civilians or noncombatants caught in the war zone) and to those who offer alternative viewpoints (Ettema, 1994). Ettema argues that an understanding of the meaning of war requires listening to the voices of those who live it. Understanding the victims' stories provides readers and viewers with the opportunity to exercise empathy, which, in turn, can provide the basis for moral actions (Eisenberg, 2000).

The war victims Ettema and others (Chouliaraki, 2005; Kellner, 2004) refer to are those who directly suffer war's human costs, although they are not, generally, directly involved in political decisions leading to the conflict. Citizens who have not experienced war first hand are not victims in the usual sense. But the family members of active combat soldiers, who remain outside the war zone, have much to tell about their own experiences with war. Thus, we broaden Ettema's category of "victims" to include relatives of soldiers who share in the burden of war.

This study focuses on the stories that the news media tells about one group of relatives who remain on the home front: mothers of combat soldiers. More specifically, we ask: How do the national news media depict mothers of United States combat soldier in stories related to the Iraq War? We recognize that wives, husbands, fathers and children all have stories to tell but we separately examine the role of mothers in the war stories for several reasons (each is further amplified in the next section). First, as in most cultures, the symbol of motherhood is accorded high status in the United States. Lule (2001) points out that the archetypal good mother is portrayed in news narratives as selfless, protective and caring. She does much of the childrearing during the first eighteen years of a child's life, and her efforts, according to Ruddick (1989), are grounded in preservative love, i.e., efforts to keep her child safe. Her antithesis is the uncaring bad mother, who willingly harms her own child or allows her child to be harmed (Barnett, 2004).

The symbol of the good mother appears consistent with another important cultural symbol, the patriotic mother. The archetype of the

Critical Studies in Media Communication, Vol. 24, No. 5 (2007): pg. 429-445. DOI. This article is @ Taylor \& Francis (Routledge) and permission has been granted for this version to appear in e-Publications@Marquette. Taylor \& Francis (Routledge) does not grant permission for this article to be further copied/distributed or hosted elsewhere without the express permission from Taylor \& Francis (Routledge). 
patriotic mother is a supporting and caring mother who is also stoic, silent and brave in the face of war. She unfailingly supports the nation's war effort and her child's participation in it, despite the threat of death to her child (Ziegler, 1996). This cultural assumption about the patriotic mother appears to conflict with the assumption routinely made about the archetypal good mother; that is, she tries to protect her child from death. This subtle but important distinction raises a question about how the news media portrays of mothers of combat soldiers during wartime.

No systematic studies exist about how the press invokes the powerful symbol of motherhood when the nation is at war. But, a growing body of feminist scholarship suggests that the relationship between women and war has historically been confusing (Elshtain, 1987). The idea of motherhood has been used to support war as well as peace during the last century (de Alwis, 1998; Scheper-Hughes, 1998). Therefore, a study of how the press symbolizes mothers of combat soldiers is timely and warranted.

Second, the study is important because news reportage functions as myth-making in this culture (Lule, 2001). Mass-mediated messages and symbols "inculcate individuals with the values, beliefs, and codes of behavior that will integrate them into the institutional structure of the larger society" (Herman \& Chomsky, 1998, p. 1). News as myth tells us what to value, who is important, how to behave, and often supports the status quo (Lule, 2001).

Third, most maternal work quietly occurs in the private rather than in the public sphere, where politics is generally assumed to reside. But, the private sphere is also political because the state legally defines family boundaries, including who counts as members and which behaviors are acceptable (Okin, 1989). We argue that mothers have much to contribute to the public political discussion of what it means to be at war. Systematically examining wartime news accounts provides a closer understanding of how mothers appear to respond to the problem of sending children into combat, and allows us to attend to what they are saying about their experiences.

Our goal is to examine how the national news media represents the mothers of combat soldiers during wartime, specifically during the

Critical Studies in Media Communication, Vol. 24, No. 5 (2007): pg. 429-445. DOI. This article is @ Taylor \& Francis (Routledge) and permission has been granted for this version to appear in e-Publications@Marquette. Taylor \& Francis (Routledge) does not grant permission for this article to be further copied/distributed or hosted elsewhere without the express permission from Taylor \& Francis (Routledge). 
U. S./Iraq War. Our analysis is guided by a theoretical framework that rests on the concept of maternal work, which we situate within an ethic of care. We also examine how symbols of motherhood and their relationship to war have been framed in our culture's narratives in an effort to better understand the role that the media assign to mothers of soldiers during wartime.

\section{Mothers and War}

\section{The Private Sphere}

Ruddick (1989) anchors the phenomenon of maternal thinking in the practice of protecting the children physically and fostering their growth. Maternal thinking, says Ruddick, is a specific type of moral and political reasoning that derives from experience in caring for the young physically, emotionally and socially and in the ways that humans interact and engage one another. Maternal workers are not necessarily biological mothers or even female. Assuming that ways of knowing and thinking are rooted in actual experience, Ruddick argues that men as well as women engage in maternal work, most of it within the home. The understanding and knowledge that results from maternal practice, rather than instinct, may influence maternal workers' leanings toward pacifism. Thus, Ruddick argues, maternal work is a "'natural resource' for peace politics" (p. 157). Her argument is central to this study.

Scholars disagree about the existence of a maternal inclination toward pacifism. In the 1980s some Nicaraguan mothers, for instance, not only gave up their sons to the cause, but also joined them in the revolutionary struggle (de Volo, 1998, 2001). Other scholars argue that maternal responses to war are not fixed. While some mothers have worked to promote peace, other mothers have "fought in wars and now often seek equal treatment in the militaries of many countries" (Turpin, 1998, p. 9). ${ }^{1}$ These varied responses may be related to the social, historical and political contexts in which the mothers find themselves (de Alwis, 1998). Scheper-Hughes (1998) noted that some mothers may hate the idea of war, but accommodate conflict because their "public thoughts are so rarely solicited," and they live in a world where "maternal values and thinking count for little" ( $p$. 228). She also argues that mothers are socialized to accept their

Critical Studies in Media Communication, Vol. 24, No. 5 (2007): pg. 429-445. DOI. This article is (C) Taylor \& Francis (Routledge) and permission has been granted for this version to appear in e-Publications@Marquette. Taylor \& Francis (Routledge) does not grant permission for this article to be further copied/distributed or hosted elsewhere without the express permission from Taylor \& Francis (Routledge). 
children's "horrible deaths" (p. 231). Without such acceptance, the military could not move forward (Scheper-Hughes 1998; Marvin \& Ingle, 1999).

While this debate remains unsettled, we believe that Ruddick's notion of maternal thinking is worth considering as it relates to conflict. Further, it dovetails with Gilligan's (1977) broader concept of an ethic of care, a moral philosophy that rests on human connectedness and is grounded in love, respect and responsibility. Care for others, as well as the self, provides the impetus for moral behavior. Gilligan's ethic of care contrasts with the ethic of justice, a moral philosophy that emphasizes individualism, separation and autonomy and rests on abstract moral principles. The ethic of justice, she argued, is the predominant moral philosophy in the public sphere, rather than the ethic of care that often marks a mother's relationship with her children in the private sphere.

Scholars have criticized Gilligan and others for essentializing women when articulating the ethic of care, and have also argued that the notion of care as matter of the private sphere is too limiting (Okin, 1989; Steiner, 1989; Steiner \& Okrusch, 2006). But issues of connectedness and distance can be accounted for, according to Pech and Leibel (2006), by distinguishing between caring "for" the other and caring "about" the other (p. 143). At the same time, debate surrounds the relationship between the ethics of care and justice. Some have privileged justice (Kohlberg, 1981; Rawls, 1971), while others, including feminists and theologians, have privileged care (Okin, 1989), with some arguing that social justice is one form of care (Jacobson \& Sawatsky, 2006). Despite these and other challenges to Gilligan's articulation of the ethic of care, we believe that her perspective is generally reflective of Ruddick's views on maternal thinking and is useful to this study. With this in mind, we turn to the discussion of symbols of wartime motherhood and how they have played out in the public sphere.

\section{The Public Sphere}

The ideology of the patriotic mother can be traced back to the beginning of the republic, when women lacked an independent political identity and public voice. The early Republican Mother was expected to remain at home and instill virtue in her children by encouraging her

Critical Studies in Media Communication, Vol. 24, No. 5 (2007): pg. 429-445. DOI. This article is (C) Taylor \& Francis (Routledge) and permission has been granted for this version to appear in e-Publications@Marquette. Taylor \& Francis (Routledge) does not grant permission for this article to be further copied/distributed or hosted elsewhere without the express permission from Taylor \& Francis (Routledge). 
sons to actively participate in civic life (Kerber, 1986). Women began to move into the public sphere following the Civil War when a shared belief emerged that women had a responsibility to promote virtue and morality in the wider society (Cutter, 2003). This ideology of Redemptive Womanhood developed with the rise of the free market society. The Redemptive Mother, like the Republican Mother, was characterized as nurturing, loving and unselfish. However, these values of the good mother contrasted with values necessary for marketplace success. Redemptive Women, therefore, moved into wider society to assume responsibility for the country's moral health as well as that of their husbands and children. Suffragist Jane Addams noted that reform work in the public sphere was part of "municipal housekeeping and political extensions of motherhood" (Cutter, p. 198). At this time we begin to see mothers' political positions made public vis a vis war and their son's involvement in the conflict.

When peace activists and maternalists began challenging the proposed draft before the First World War, the Wilson Administration viewed the activists, many also suffragists, as a threat to the nation's morale and used images of virtuous mothers of patriotic sons to counter the opposition (Zeigler, 1996). For example, the government's wartime propaganda office, the Committee on War Information, distributed literature illustrating a "good mother" as one who supported her son's willingness to be drafted and fight in Europe (Ziegler, 1996). The government's vision of the patriotic mother was projected on to the silver screen by the fledgling movie industry. The storyline in a series of wartime films involved a conflict between a mother and son over the draft, the mother initially appearing as overbearing and selfish. The story ending portrayed the mother as having come around to her son's, i.e., the patriotic soldier's, point of view (Zeigler, 1996).

The norm of the patriotic mother was further pushed into the center of the nation's psyche during the Second World War. Philip Wylie distinguished the "good mother" from a "mom" in his best selling collection of essays, Generation of Vipers, first published in 1942 and many other times between 1942 and 1955. Wylie, dismayed that some men were reticent about joining the wartime military, blamed "moms" for failing to raise sons to be proper citizens.

Critical Studies in Media Communication, Vol. 24, No. 5 (2007): pg. 429-445. DOI. This article is @ Taylor \& Francis (Routledge) and permission has been granted for this version to appear in e-Publications@Marquette. Taylor \& Francis (Routledge) does not grant permission for this article to be further copied/distributed or hosted elsewhere without the express permission from Taylor \& Francis (Routledge). 
This normative vision of the patriotic mother received a scientific patina in the best seller, Their Mothers' Sons: A Psychiatrist Examines an American Problem. Psychiatrist Edward Strecker (1946) cited "poor mothering" as the reason millions of men were unfit for combat. "Moms," according to Strecker, refused to untie the "silver apron strings," stunting their sons' ability to defend the nation in war. Thus, mothers were blamed when their sons were discharged for "psychoneurosis" (Strecker, 1946, p. 35).

In the decades since World War II, symbols of patriotic motherhood have appeared in popular culture. For instance, flags draped on caskets and later placed in the arms of mothers or wives, as well as gold star flags in windows, tell the nation that soldiers were martyred; they died a meaningful heroic death. Marvin and Ingle (1999) argue that cultural mythology surrounding the American flag suggests that mothers sacrifice "twice...first bearing children, and then offering them for war" (p. 57). In war stories related to patriotic motherhood, death becomes purposeful, and the "rage and grief for those whose lives were unnecessarily lost or taken is extinguished" (Scheper-Hughes, 1998, p. 230).

At the same time, controversy has followed peace activists, many of them women and mothers. For example, women peace activists who opposed nuclear proliferation during the 1960's were investigated by the federal government on the grounds that Communists infiltrated their ranks (Echols, 1993; Ware, 1997). The mother of a slain Vietnam soldier garnered negative attention from the military and its supporters after she publicly criticized the U. S. effort in Southeast Asia (Mullens, 1995). One activist who served prison time for her peace efforts, Judith Williams, said her work is grounded in an "inner passion related to being a nurturer" (Williams, personal communication, August 19, 2004). More recently, Cindy Sheehan ignited controversy when she began protesting the Iraq war in which her son died. Sheehan, co-founder of Gold Star Mothers Against the War, said publicly that she holds President Bush, responsible for her son's death (Gold, 2004, p. 114).

This discussion underscores the fact that dissention has its price (e.g., jail, negative attention) including the implicit assumption that dissenters are bad mothers. Indeed, the culture has made an effort at the "symbolic mobilization" of motherhood during military conflicts and

Critical Studies in Media Communication, Vol. 24, No. 5 (2007): pg. 429-445. DOI. This article is @ Taylor \& Francis (Routledge) and permission has been granted for this version to appear in e-Publications@Marquette. Taylor \& Francis (Routledge) does not grant permission for this article to be further copied/distributed or hosted elsewhere without the express permission from Taylor \& Francis (Routledge). 
build-ups that functions as a way of socializing mothers into their proper wartime roles. Enloe (2000) situates this phenomenon within the larger problem of the "militarization" of U.S. culture. The process whereby individuals believe that their well-being depends on "militaristic ideas" (p. 3) is perpetuated by individuals, as well as the government, the military and other social institutions such as education and mass media. The ideal mother in this context is the good mother who avoids dissention. Her support the war effort furthers the unified voice of the citizenry around a cause; a nation run by citizens cannot proceed toward war without their consensus (de Volo, 1998).

In summary, American mothers have generally appeared to express public support for the nation's war efforts. But, by paying attention to the issues of maternal work, maternal thinking and an ethic of care, scholars have laid a thoughtful foundation during the last quarter century for the claim that, perhaps, support for a war effort is counterintuitive to maternal work and maternal thinking. With this contradiction in mind, we wondered how the news media symbolized mothers of soldiers during wartime. Because no studies specifically address the issue of the war-related news and motherhood, we ask: How do the national news media depict the mothers of $U$. S. combat soldiers in stories related to the Iraq War?

\section{Method}

We examined the news coverage of the Iraq War in three national newspapers, the New York Times, the Washington Post, and USA Today during three time periods. The first period was February 21 until April 17, 2003; and this was chosen because this included the time leading up to the war through the day President Bush announced "Mission Accomplished." We returned to the same time frames in 2004 and 2005 because they marked the anniversaries of the initial invasion. A keyword search in a Lexis-Nexus data base search turned up, a total of 15,000 stories during these time frames.

Following Lule (1995), we did a textual analysis of each of the 125 news stories in which any reference to any mothers of combat solders appeared; and we also examined direct quotes attributed to mothers. Textual analysis is an effective means for exploring "how stereotypical depictions are invoked through the language and

Critical Studies in Media Communication, Vol. 24, No. 5 (2007): pg. 429-445. DOI. This article is @ Taylor \& Francis (Routledge) and permission has been granted for this version to appear in e-Publications@Marquette. Taylor \& Francis (Routledge) does not grant permission for this article to be further copied/distributed or hosted elsewhere without the express permission from Taylor \& Francis (Routledge). 
conventions of the press" (Lule, 1995, p. 177). Hall (1975) argues that it is useful for "penetrating the latent meaning," while still preserving "something of the complexity of the language and connotation" of the text ( $p .15$ ). This focus on the text requires a "long preliminary soak" (Hall, 1975, p. 15) and multiple readings to uncover themes and patterns evident within. This allows us to resituate and discuss the news stories in terms of their social and political implications (du Gay, Hall, Janes, Mackay and Negus, 1997).

Two authors and a graduate student independently examined the stories using a constant comparative method and identified story themes in an effort to capture the range of depictions of mothers of combat soldiers in wartime news coverage. The individual lists of elements were collated and compared. Disagreements were resolved through discussion and re-readings of the text.

Before turning to the analysis, it is important to mention that the number of war stories involving mothers of soldiers is limited. Mothers began appearing in news stories three weeks after the war started, about the time the news media began to regularly report on casualties. Mothers appeared in 48 stories in the New York Times, 52 stories in the Washington Post and in 25 stories in the USA Today. A total of 134 mothers appeared in the stories. Some mothers appeared in more than one newspaper, as some were mothers of prisoners of war captured and released during March of 2003. USA Today had roughly half the number of stories of the other papers, but there was no substantive difference between the newspapers in terms of the coverage of mothers' wartime roles, as described below. Finally, all mothers were from the U.S. with the exception of two; one was Mexican and the other an immigrant mother from an unspecified Muslim country. Both had sons who were in the U.S. military fighting in Iraq.

\section{Reconciling the Good Mother and the Patriotic Mother}

Our analysis revealed that journalists constructed an image of mothers of soldiers through the symbol of the good mother. The good mother is depicted as carrying on her maternal work after the soldier is deployed. The nature of that work is based on what the good mother knows about her child's situation. At the same time, this symbolic

Critical Studies in Media Communication, Vol. 24, No. 5 (2007): pg. 429-445. DOI. This article is @ Taylor \& Francis (Routledge) and permission has been granted for this version to appear in e-Publications@Marquette. Taylor \& Francis (Routledge) does not grant permission for this article to be further copied/distributed or hosted elsewhere without the express permission from Taylor \& Francis (Routledge). 
construction of the soldier's mother does not assume silence and stoicism; a key component of the archetypal patriotic mother. Journalists allowed mothers to express their opinions publicly and privately; these opinions ranged from complete support for the nation's war effort to opposition to the war. But, mothers were also shown as uniformly supporting their children in combat.

Ruddick's (1989) theory of maternal work provides a useful framework for understanding how image of mothers of combat soldiers is constructed. She argues that the "preeminent" element of maternal work, the physical protection of the child, is a response to the fragility of children and the length of time it takes for them to learn to capably care for themselves (p. 18). A second element involves nurturing children emotionally and intellectually. Ruddick acknowledges that others have direct interests in children's development, but argues that, in this culture, mothers have assumed the primary responsibility for ensuring that conditions are right for children's emotional and intellectual growth. The third element involves training the child to be socially acceptable. Maternal work includes shaping the child so that he or she is acceptable to those in the mother's social network, the larger culture and to the mother herself. A mother fulfills the cultural demand that her children be properly socialized. According to Ruddick (1989), "training a child to be the kind of person whom others accept and whom the mothers themselves can actively appreciate" is central to the process of mothering for many mothers; appropriate socialization of the child often marks the success or failure of a mother (p. 104).

News narratives analyzed for this study depicted mothers as continuing the three essential elements of maternal work even when their children were fighting in Iraq. Further, the degree to which a mother engaged in any of these forms of maternal work was related to her perceptions of the physical whereabouts of her child as well as her child's place in the cycle of wartime service (including enlistment, training, deployment, in combat, captured, injured, killed, returned home, etc.) We call her effort to learn about her child during this cycle the "watchful eye" and identify three moments that played an important role in shaping the mothers' wartime efforts and appeared to be most relevant to the journalists' storytelling. These three moments include: when the mother perceives the soldier to be in

Critical Studies in Media Communication, Vol. 24, No. 5 (2007): pg. 429-445. DOI. This article is @ Taylor \& Francis (Routledge) and permission has been granted for this version to appear in e-Publications@Marquette. Taylor \& Francis (Routledge) does not grant permission for this article to be further copied/distributed or hosted elsewhere without the express permission from Taylor \& Francis (Routledge). 
danger, usually in the battle zone; when she perceives the soldier to be in heightened danger, for example, listed either as missing in action, captured or injured; and when she perceives a resolution to the soldier's status, for example, the solider is safely out of the war zone or has been killed in action.

\section{"A Watchful Eye"}

Good mothers watch over their children because they can come to harm; the maternal worker "must be alert for things that go wrong and be ready to set them right" (Ruddick,1989, p. 71). The news coverage suggested this process did not stop just because the children were grown. Journalists depicted mothers as actively surveying their environment for information on the whereabouts of their children during wartime. Most mothers were described as relying heavily on the mass media for information; while television was the primary source, mothers also used the internet for information about their children in the battle zone. For example, mothers saw images of their sons and daughters at war. One mother reportedly thanked CNN News anchor Aaron Brown for "allowing me to sit with my son as he crossed the desert" (Purdum \& Rutenberg, 2003). Another mother, who relied on television, e-mail and weblogs, marveled at real-time communication (Richtel, 2003). Not all mothers were depicted as responding positively to instant communication. One, for instance, viewed footage of her son's helicopter crash and criticized news media for showing such images (Johnson, 2003).

Journalists described face-to-face encounters with military officials as another way that mothers learned about their children's wartime status. The coverage suggested mothers of soldiers had an equivocal relationship with the military. Several mothers reportedly responded to the traditional "knock on the door" by officers in dress uniform in horror or disbelief, or even trying to flee. At times, however, other mothers were depicted as wanting the contact and appeared to depend on the military for information when their children were reported missing in action (Polgreen, 2003).

Journalists also described mothers' using intuition as a means of knowing about their children's fate. One mother said she had the feeling that her son would be fine during his tour of duty, describing it as "probably...a mother thing" (Hockstader \& Vendantam, 2003). Other

Critical Studies in Media Communication, Vol. 24, No. 5 (2007): pg. 429-445. DOI. This article is @ Taylor \& Francis (Routledge) and permission has been granted for this version to appear in e-Publications@Marquette. Taylor \& Francis (Routledge) does not grant permission for this article to be further copied/distributed or hosted elsewhere without the express permission from Taylor \& Francis (Routledge). 
mothers described feelings of foreboding. One mother's sense of foreboding was so strong she started planning her son's funeral on the day he left, explaining "I knew in my heart ... he wasn't going to be coming home" (Partlow, 2004). Family members reportedly told the mother to stop planning the funeral. The reporter didn't comment on the nature of the mother's action or the family response, possibly because the mother had been right, her son was killed. Overall, the news stories treated mother's intuition as a legitimate way of knowing and as a normal way that mothers demonstrated worry for their children.

In danger. News accounts indicated that mothers made an effort to care for their children physically, emotionally and socially when they perceived their children were in danger. The accounts also reported that many mothers did this work with other mothers and families of combat soldiers. Mothers were depicted sending care packages, food, blankets and clothing, in an attempt to meet physical needs that might otherwise be unmet. Along with these items, care also arrived in the form of maternal advice on safety; when one mother learned of her daughter's involvement in an attack, for instance, she advised her to "keep her gas mask on" (Richtel, 2003). The press also described mothers' efforts to provide emotional and spiritual support, an important component of maternal work (Ruddick, 1989). For example, one mother reported said her son asked her on three separate occasions if the Lord would forgive him if he had to kill someone. She assured him that he would be forgiven "if he had to do that" (Gootman \& Lueck, 2003).

All of these actions where reported without challenge. In other words, none of these behaviors were described as "overbearing," as Wiley (1955) suggested, or as unusual or atypical. Despite the fact that the children were all grown, these nurturing activities were presented as normative. This news coverage implied that mothers tried to anticipate or meet their children's physical and emotional needs; and that these behaviors apparently benefited the children.

The third element of maternal work, i.e., socializing the child, is a result of a demand made by the larger culture, rather than a demand of the children themselves. Society presses maternal workers to socialize the child to fit into the larger social order. A maternal worker's success is evaluated, in part, on the child's social

Critical Studies in Media Communication, Vol. 24, No. 5 (2007): pg. 429-445. DOI. This article is @ Taylor \& Francis (Routledge) and permission has been granted for this version to appear in e-Publications@Marquette. Taylor \& Francis (Routledge) does not grant permission for this article to be further copied/distributed or hosted elsewhere without the express permission from Taylor \& Francis (Routledge). 
acceptability (Ruddick, 1989). These news stories suggested that the soldiers were properly raised by their mothers. Mothers described their adult children in terms of activities and behaviors characteristic of good citizens. For instance, one mother was quoted as saying her son had always been self-supporting, adding "I just never did have to worry about him" (Yoo, 2003), while another said that her physician son told her that he cared deeply for his fellow soldiers and that they were "some of the finest men and women" he had ever met (Briggs, 2003). By including these types of quotes, the press affords mothers the opportunity to suggest that they had successfully raised their children to be socially acceptable. We found no difference in the ways mothers spoke about their sons and daughters; because of the small numbers of female soldiers in this sample it is difficult to determine if mothers would speak differently. This cooperative effort by the news media and the mothers to build an image of a properly socialized child only indirectly benefits the child but directly benefits the mother by assuring her status as a good mother. Finally, as will be discussed later, the inclusion of these quotes by the press presents the public with the raw material needed to build an image of the soldier as hero.

Captured or injured. The news stories revealed a shift in maternal work when mothers learned that their children were either captured or missing in action. News reports suggested that mothers of captured soldiers stopped sending care packages and letters and, instead, focused on spiritual support for their child and themselves, largely through prayer (Yardley, 2003). While a mother's efforts to provide material care were on hold, her concern about a son or daughter's physical well-being was still very much in evidence. One news story, for example, described a mother as feeling guilty about eating when she wasn't sure if her son had food, and sleeping in a bed when she was not sure if her son was "getting any sleep" (El Nasser, 2003). In contrast, mothers in news stories about injured soldiers were depicted as continuing the maternal work of physically caring for the child. For instance, one news story described a mother calling the hospital in Germany where her injured son was staying and asking the nurse to put the phone receiver on his pillow so he could hear her voice. Once reunited, she helped care for her son by rubbing salve on his burns and supporting him emotionally when doctors said that his leg must be amputated (Herbert, 2004). This portrayal of mothers as willing to go to great lengths to continue their maternal work suggests

Critical Studies in Media Communication, Vol. 24, No. 5 (2007): pg. 429-445. DOI. This article is (C) Taylor \& Francis (Routledge) and permission has been granted for this version to appear in e-Publications@Marquette. Taylor \& Francis (Routledge) does not grant permission for this article to be further copied/distributed or hosted elsewhere without the express permission from Taylor \& Francis (Routledge). 
that such efforts were normal and within the bound of ordinary cultural expectations.

In new stories of captured and injured soldiers, the press continued to provide mothers with the opportunity to build images of their children as properly socialized. One described her captured son as "a man's man" who was "eager to get into action" and "make his country proud," while another said her son's "tenacity and stubbornness will get him through this" (Kelley, 2003). Jane Riley said her son's "life's choice" was military service, despite its risks (Marshall, 2003). These image building quotes portray the child as socially valuable; worthy of attention and honor. Further, these quotes implicitly suggest that these soldiers were raised by good mothers.

When prayers are not answered. Journalist's described a mother's worst fear as having a son or daughter "come back in a coffin" (Kelley 2003). Stories related to the deaths of soldiers in Iraq accounted for more that a third of the 125 stories in the sample. Maternal responses described in the stories ranged from denial and devastation, to sleeplessness and an inability to eat, to wandering "distraught around the neighborhood" (Halbfinger, 2003).

In these narratives, mothers could do little materially for their child beyond arranging funerals. Continued spiritual care was reflected in a mother's prayers. News accounts also suggested that maternal work continued in the form of building images of the child as socially acceptable. As one might naturally expect, dead sons and daughters were described in terms of their socially desirable qualities including compassion and willingness to help others (Goldstein, 2003). The news coverage suggested that while the mother lost a child, society lost a good citizen.

In addition to losing good citizens, the coverage also indicated that society lost good heroic soldiers. Beyond the types of character traits that normally surface during conversations about someone newly dead, these children were described in relation to their country, with an emphasis on patriotism and responsibility to fellow citizens. One mother said her son loved the military and that he was "ready to go to Iraq and get the war done" (Howlett, 2003). Several mothers noted that their children had been changed by the military experience, evolving into more confident, patient and respectful human beings as a

Critical Studies in Media Communication, Vol. 24, No. 5 (2007): pg. 429-445. DOI. This article is (C) Taylor \& Francis (Routledge) and permission has been granted for this version to appear in e-Publications@Marquette. Taylor \& Francis (Routledge) does not grant permission for this article to be further copied/distributed or hosted elsewhere without the express permission from Taylor \& Francis (Routledge). 
result of joining the service. Sons and daughters were also described as being proud, willingly giving their lives to defend freedom and country, and of being aware of their duty.

While journalists depicted these mothers as building images of good citizens and good soldiers, the implication was that mothers wanted, above all else, respect and honor for their children. This was true even for soldiers who were described in ways that raised questions about their capacity for being good soldiers. For example, when one soldier committed suicide by overdosing on drugs; his mother explained his death by saying that he "wasn't war material" and that he still deserved honor (Labbe, 2004).

In the above examples, we have seen how journalists construct the image of the good mother by drawing upon the three types of maternal work. Journalists portrayed the good mother as continuing to care for her child despite the fact that her child is grown and gone. While these mothers of soldiers meet the first component of the patriotic mother by being good mothers they do not necessarily meet the historical expectation of stoicism and silence.

\section{The Patriotic Mother: Code of Silence Revisited}

The press depicted mothers of soldiers as having diverse opinions about the war itself, ranging from support for the war to total opposition. Journalists allowed mothers to voice opinions about the Iraq War in 37 stories in the sample. On third of the mothers who voiced opinions offered support for the nation's war effort. Some were depicted as joining support groups of like-minded people. Several of these mothers said they viewed anti-war protesters as wrongheaded and wished they would stop protesting, in part, because they did not want their children to come back "ashamed," as soldiers did when they returned from Vietnam (St. George, 2003). But several also acknowledged the opposition's right to speak against the war. One mother observed that her son sacrificed his life for this right, adding that the same group would be up in arms "if Saddam did to cats and dogs what he does to humans..." (Edsall, 2003).

A few mothers were depicted as having mixed feelings about the war. These mothers said that they were torn because they opposed the war personally, but did not want to protest the nation's war effort publicly because they had children in the military. USA Today, for

Critical Studies in Media Communication, Vol. 24, No. 5 (2007): pg. 429-445. DOI. This article is (C) Taylor \& Francis (Routledge) and permission has been granted for this version to appear in e-Publications@Marquette. Taylor \& Francis (Routledge) does not grant permission for this article to be further copied/distributed or hosted elsewhere without the express permission from Taylor \& Francis (Routledge). 
example, described one mother as displaying both a yellow ribbon and an anti-war poster in her home (Copeland \& Alvord, 2003).

Two-thirds of the stories in this group contained some expression of anti-war sentiment. Stories in which mothers publicly protested their feelings began appearing soon after the war started in 2003. Mothers of soldiers, both living and dead, participated in the protests. Nancy Lessen, the mother of a Marine serving in Iraq and cofounder of the anti-war group Military Families Speak Out, told a reporter of a code of silence against speaking out against the Iraq War. But, she argued, the nation's sons and daughters should not be used "as cannon fodder" (Davey, 2004). Anti-war activist Cindy Sheehan said that she and others were trying to "make people care about what's going on over there" (Nieves, 2005).

Expressions of anger and frustration were not limited to those mothers who spoke in a public and organized way. Other mothers reacted to war news at funerals, in their homes, in their workplaces and other venues, expressing disappointment and anger about the war. While stirring a pot on the stove in her kitchen, an Iowa mother claimed that the Bush administration had no idea what was going to happen after the fall of Saddam Hussain. Said Ilene Deutsch, "Surely [the President] didn't look at the long range.... He didn't have a clue" (Maraniss, 2004). When the body of one dead soldier was returned to Mexico where his family lived, his mother blamed a U. S. recruiter for her son's death. She wanted to refuse the American flag for her son's coffin but was, according to the report, talked out of it (McKinley, 2005). Finally, Patricia Roberts was making funeral arrangements when she told a reporter she "would rather my son be a coward in my arms than Bush's hero" (Hull \& Goldstein, 2003).

Regardless of their feelings about the war, mothers were careful to distinguish between the war and the soldiers who were fighting in it. Mothers uniformly expressed support for their children and, as noted earlier, wanted others to respect and honor their children as well. The limited sample does not reveal whether mothers' opinions of the war changed over time. It does suggest that a mother's reaction to the war did not depend on the status of her child; mothers of living and dead soldiers expressed either opposition to or support for the war. However, mothers of POWs did not express a viewpoint. They may not have been asked, or they may have declined comment.

Critical Studies in Media Communication, Vol. 24, No. 5 (2007): pg. 429-445. DOI. This article is @ Taylor \& Francis (Routledge) and permission has been granted for this version to appear in e-Publications@Marquette. Taylor \& Francis (Routledge) does not grant permission for this article to be further copied/distributed or hosted elsewhere without the express permission from Taylor \& Francis (Routledge). 
NOT THE PUBLISHED VERSION; this is the author's final, peer-reviewed manuscript. The published version may be accessed by following the link in the citation at the bottom of the page.

The coverage of these mothers' opinions appeared, overall, to be balanced. The presentation of attitudes both favoring and opposing the war created a sense of evenhandedness on the part of the press. The mothers of soldiers who opposed the war were depicted as distinguishing between the war and the warrior; they offered unconditional support for their soldier children, the warriors, but not the war itself. Journalists situated mothers of soldiers who opposed the war in both the public and private spheres. Some mothers recognized they were expected to remain silent regarding their feelings about the war. Some were willing ignore this code of silence and in doing so appeared willing to risk criticism for publicly sharing their feelings.

\section{Conclusions/Discussion}

The overarching news narrative that emerged suggests that the present day picture of wartime motherhood is more nuanced and complex than the myth of the patriotic mother has allowed. The analysis revealed that the image of mothers of combat soldiers created by the press is grounded in the notion of the archetypal good mother. Mothers of soldiers are shown to continue to care for their children in ways outlined by Ruddick (1989); these mothers care for their children physically and emotionally while continuing to ensure that society perceives them as being properly socialized good citizens and soldiers. That dimension of the archetypal good mother dovetails with that of the archetypal patriotic mother. Unlike the archetype of patriotic mother, however, the mothers of combat soldiers in this sample were not depicted as necessarily stoic and silent. While all mothers supported their children who were in combat, some clearly did not support the war. To the extent that the mothers of soldiers in the Iraq War opposed the nation's war effort, their image created by the press does not completely reflect the historical image of the patriotic mother.

This nuanced view raises the question: Why doesn't this image of mothers of soldiers in Iraq match the historical archetype of the patriotic mother? There may be multiple reasons. First, perhaps the assumption, that the patriotic mother is the good mother who willingly and silently sends her child into combat, is invalid. Mothers of soldiers may have historically been silent but it is unknown whether it was a willing silence on their part. Mothers may now be more willing to voice opinions about war than they were in the past. History suggests that

Critical Studies in Media Communication, Vol. 24, No. 5 (2007): pg. 429-445. DOI. This article is (C) Taylor \& Francis (Routledge) and permission has been granted for this version to appear in e-Publications@Marquette. Taylor \& Francis (Routledge) does not grant permission for this article to be further copied/distributed or hosted elsewhere without the express permission from Taylor \& Francis (Routledge). 
mothers and other pacifists openly expressed opposition prior to World War I but were subsequently discouraged by the government and others. More recently, public opposition to the Vietnam War may have laid the groundwork for mothers' willingness to more openly express their opinions regarding the Iraq War, with many taking care to distinguish between supporting their sons and daughters and opposing the war, thus avoiding the problem of shaming their children. Second, emerging technology allows those with divergent viewpoints to communicate with broad audiences in ways never before possible. Instant communication with others here and abroad makes it difficult for the mainstream press to ignore these views. Third, journalistic practices may have changed across various wars but without comparative data we can draw no conclusions. More research is needed to determine whether the press depiction of mothers of soldiers has changed over time and, if so, how. Such a study might shed light on whether the cultural image of the patriotic mother is changing. Understanding the impact of presidential administrations on war coverage of mothers would also be of value. Further, this study focused on national news coverage; local news coverage might offer another view of mothers with more contextual detail.

Journalists cast mothers of combat soldiers in this coverage in the role of caregiver and in some instances, caregivers who expressed their opinions about the war to the news media. The news emphasis on the role of maternal work positions the mother as having successfully completed an important function of child-rearing. It also casts the child as a valued citizen or hero, putting a mother in tandem with the press, the military and the culture, in a position to justify the death of her child, should that occur. Upon the death of a child, the caring mother receives honor and recognition, symbolized by the American flag, in exchange for her child (Marvin \& Ingle, 1999). This symbolic ritual, in turn, allows the cycle of war to continue (Enloe, 2000).

However, the range of views that journalists allowed mothers to voice in these stories suggest that we cannot and should not rule out Ruddick's (1989) position that maternal work may be an incipient resource for peace politics. These wartime accounts, albeit limited, suggest that mothers have much to say about what it is like to have children in combat. The public's knowledge of the mother's personal

Critical Studies in Media Communication, Vol. 24, No. 5 (2007): pg. 429-445. DOI. This article is @ Taylor \& Francis (Routledge) and permission has been granted for this version to appear in e-Publications@Marquette. Taylor \& Francis (Routledge) does not grant permission for this article to be further copied/distributed or hosted elsewhere without the express permission from Taylor \& Francis (Routledge). 
cost of sending children into battle, widely shared has the potential to shape the larger democratic debates about war.

We limited this study to mothers, but note that fathers, wives, girlfriends, and husbands, as well as others who are important in a soldier's life, appeared in these narratives. Their reactions to events were varied and intense. Their roles in news of war deserve serious scholarly attention. Social justice requires that we recognize the claims of others in our moral decision-making (Rawls, 1971). It follows that the press and interested citizens alike have a moral obligation to seek out and listen to the voices of those who pay the dearest prices for our collective decisions including all of those who share in the burden of war. Their stories and points of view leading up to the war, in particular, could force the citizenry to ask whether there are more merciful ways to resolve conflict.

The terms used to label the individuals who share in the burden of war reflect social constructions that are relational in nature. The terms mother and father, for instance, suggest children, the term husband suggests wife, and the term sister suggests brother. The way people are labeled carries certain assumptions about their responses to sending loved ones into combat. These labels also inform us that we must confront the experiences and responses of these people from the viewpoint of interdependence, a viewpoint that demands that we consider their reactions to emotional pain and loss as connected individuals. The alternative is to consider them as autonomous and anonymous members of the larger general public, whose loss may count as "the nation's loss" but is really no one's loss in particular. It is the particularity of their losses that Ettema (1994) has argued we must come to know through the narratives offered by wartime journalists. These kinds of stories, he insists, invite us to identify with the lives of others, and in doing so, foster a "loathing" for that which is cruel and inhumane.

Critical Studies in Media Communication, Vol. 24, No. 5 (2007): pg. 429-445. DOI. This article is (C) Taylor \& Francis (Routledge) and permission has been granted for this version to appear in e-Publications@Marquette. Taylor \& Francis (Routledge) does not grant permission for this article to be further copied/distributed or hosted elsewhere without the express permission from Taylor \& Francis (Routledge). 
NOT THE PUBLISHED VERSION; this is the author's final, peer-reviewed manuscript. The published version may be accessed by following the link in the citation at the bottom of the page.

\section{References}

1. Barnett, B. (2004). Medea in the media: Maternal myths in print news coverage of women who kill their children. Paper presented at the Association for Education in Journalism and Mass Communication Annual Conference, Toronto, Canada, August, 2004.

2. Briggs, T. (2003, April 17). Keeping the faith amid the heat, casualties and critters. USA Today. Retrieved September 18, 2005 from http://www.usatoday.com

3. Bruck, P. (1989). Strategies for peace, strategies for news research. Journal of Communication, 39(1), 108-129.

4. Chouliaraki, L. (2005). Spectacular ethics: On the television footage of the Iraq war. Journal of Language and Politics, 4(1), 143-159.

5. Copeland, L. \& Alvord, V. (2003, March 21). In military towns, war a constant presence. USA Today. Retrieved September 20, 2005 from http://www.usatoday.com

6. Cutter, B. (2003). Domestic devils, battlefield angels: The radicalism of American womanhood. DeKalb, IL: Northern Illinois University Press.

7. Davey, M. (2004, April 15). The struggle for Iraq: Casualties. New York Times. Retrieved September 15, 2000 from http://www.nytimes.com

8. de Alwis, M. (1998). Moral mothers and stalwart sons: Reading binaries in a time of war. In L. Lorentzen \& J. Turpin (Eds.) Women's war reader (pp. 254- 271). New York: New York University Press.

9. de Volo, L. B. (1998). Drafting motherhood: Maternal imagery and organizations in the United States and Nicaragua. In L. A. Lorentzen \& J. Turpin (Eds.), Women's War Reader (pp. 240-253). New York: New York University Press.

10. de Volo, L. B. (2001). Mothers of heroes and martyrs: Gender identity politics in Nicaragua, 1979-1999. Baltimore, MA: The Johns Hopkins University Press.

11. du Gay, P., Hall, S., Janes, L., Mackay, H. \& Negus, K. (1997) Doing cultural studies: The story of the Sony walkman. London: Sage.

12. Echols, A (31 Dec., 1993). The mothers of invention - women strike for peace. The Nation, 257(20), 737-39.

Critical Studies in Media Communication, Vol. 24, No. 5 (2007): pg. 429-445. DOI. This article is (C) Taylor \& Francis (Routledge) and permission has been granted for this version to appear in e-Publications@Marquette. Taylor \& Francis (Routledge) does not grant permission for this article to be further copied/distributed or hosted elsewhere without the express permission from Taylor \& Francis (Routledge). 
NOT THE PUBLISHED VERSION; this is the author's final, peer-reviewed manuscript. The published version may be accessed by following the link in the citation at the bottom of the page.

13. Edsall, T. (2003, April 13). In Calif., war becomes litmus test; two areas reflect deep divide. Washington Post. Retrieved September 18, 2005 from http://www.washingtonpost.com

14. Eisenberg, N. (2000). Emotion, regulation and moral development. Annual Review of Psychology, 51, 665-697.

15. El Nasser, H. (2003, April 4). Waiting is busy agony for POW's family. USA Today. Retrieved September 18, 2005 from http://www.usatoday.com

16. Elshtain, J. B. (1987). Women and war. New York: Basic Books, Inc.

17. Enloe, C. (2000). Maneuvers: The international politics of militarizing women's lives. Berkeley, CA: University of California Press.

18. Ettema, J. (1994). Discourse that is closer to silence than to talk: The politics \& possibilities of reporting on victims of war. Critical Studies in Mass Communication, 11, 1-21.

19. Gilligan, C. (1977). "In a different voice: Women's conceptions of self and of morality." Harvard Educational Review, 47(4), 481-517.

20. Gold, E. (2004). A mother's tears: Mothers remember their sons lost in Iraq. Altedena, CA: TeleSpan Publishing Corporation.

21. Goldstein, A. (2003, March 30). Medic who died torn by duty, doubts; navy man asked for assignment in middle east. Washington Post. Retrieved September 18, 2005 from http://www.washingtonpost.com

22. Gootman, E. \& Lueck, T. (2003, April 14). Survivor's luck runs out, at last, for army's 'proud military man.' New York Times. Retrieved September 17, 2005 from http://www.nytimes.com

23. Halbfinger, D. (2003, March 24). A nation at war: The casualties; overseas, the inevitable; at home, a grim ritual. New York Times. Retrieved September 17, 2005 from http://www.nytimes.com

24. Hall, S. (1975). Introduction. In A.C.H. Smith (ed.) Paper voices: The popular press and social change (p. 11-24). London: Chatto and Windus.

Critical Studies in Media Communication, Vol. 24, No. 5 (2007): pg. 429-445. DOI. This article is (C) Taylor \& Francis (Routledge) and permission has been granted for this version to appear in e-Publications@Marquette. Taylor \& Francis (Routledge) does not grant permission for this article to be further copied/distributed or hosted elsewhere without the express permission from Taylor \& Francis (Routledge). 
NOT THE PUBLISHED VERSION; this is the author's final, peer-reviewed manuscript. The published version may be accessed by following the link in the citation at the bottom of the page.

25. Herbert, B. (2004, April 16). A soldier's sacrifice. New York Times. Retrieved September 17, 2005 from http://www.nytimes.com

26. Herman, E. \& Chomsky, N. (1988). Manufacturing consent: The political economy of the mass media. New York, NY: Pantheon Books.

27. Hockstader, L. \& Vendantam, S. (2003, April 14). Families of seven pows elated by news of their rescue; 21 days of anguish, prayer and waiting come to happy end. Washington Post. Retrieved September 18, 2003 from http://www.washingtonpost.com

28. Howlett, D. (2003, April 9). 3 die when Humvee falls into ravine. USA Today. Retrieved September 18, 2005 from http://www.usatoday.com

29. Hull, A. \& Goldstein, A. (2003, March 27). Back at home, grieving - and some questions; lack of details on deaths angers kin. Washington Post. Retrieved September 18, 2005 from http://www.washingtonpost.com

30. Jacobsen, D. \& Sawatsky, R. (2006). Gracious christianity: Living the love we profess. Grand Rapids, MU: Baker Academic.

31. Johnson, P. (2003, March 26). Reporters go along with military. USA Today. Retrieved September 18, 2005 from http://www.usatoday.com

32. Kelley, T. (2003, March 25). A nation at war: Hope; putting faith in their son's stubbornness. New York Times. Retrieved September 17, 2005 from http://www.nytimes.com

33. Kellner, D. (2004). 9/11 spectacles of terror and media manipulation: A critique of jihadist and Bush media politics. Critical discourse studies. $1: 1$, pp. $41-46$

34. Kerber, L. (1986). Women of the republic: Intellect and ideology in revolutionary America. (New York: Norton).

35. Kohlberg, L. (1981) The philosophy of moral development: Moral stages and the idea Of Justice: Essays on moral development, 1. San Francisco: Harper \& Row.

36. Labbe, T. (2004, February 19). Suicides in Iraq; questions at home; Pentagon tight- lipped as self-inflicted deaths mount in military.

Critical Studies in Media Communication, Vol. 24, No. 5 (2007): pg. 429-445. DOI. This article is (C) Taylor \& Francis (Routledge) and permission has been granted for this version to appear in e-Publications@Marquette. Taylor \& Francis (Routledge) does not grant permission for this article to be further copied/distributed or hosted elsewhere without the express permission from Taylor \& Francis (Routledge). 
NOT THE PUBLISHED VERSION; this is the author's final, peer-reviewed manuscript. The published version may be accessed by following the link in the citation at the bottom of the page.

Washington Post. Retrieved September 18, 2005 from http://www.washingtonpost.com

37. Lule, J. (1995). The rape of Mike Tyson: Race, the press and symbolic types. Critical Studies in Mass Communication, 12, 176-195.

38. Lule, J. (2001), Daily news, external stories: The mythological role of journalism. New York: Guilford.

39. Maraniss, D. (2004, March 30). Background in the heartland; Voters torn between support of military, concerns about war. The Washington Post. Retrieved September 18, 2005 from http://www.washingtonpost.com

40. Marshall, S. (2003 March 26). Families of captives in Iraq try to keep hope alive. USA Today. Retrieved September 20, 2005 from http://www.usatoday.com

41. Marvin, C. \& Ingle, D. (1999). Blood sacrifice and the nation: Totem rituals and the American flag. NY: Cambridge University Press.

42. McKinley, J. (2005, March 2). Mexican pride and death in U. S. service. New York Times. Retrieved September 17, 2005 from http://www.nytimes.com

43. Mullens, P. (1995). Unfriendly fire: A mother's memoir. Iowa City, IA: University of Iowa Press.

44. Nieves, E. (2005, February 22). For some, a loss in Iraq turns into antiwar activism; Gold Star Families band together to 'make people care.' Washington Post. Retrieved September 18, 2005 from http://www.washingtonpost.com

45. Okin, S. M. (1989). Justice, gender and the family. (U.S.A.: Basic Books, Inc.).

46. Partlow, J. (2004, February 14). Md. Soldier killed in Iraq crash; Eastern shore man survived two incidents in short time of duty. Washington Post. Retrieved September 18, 2005 from http://www.washingtonpost.com

47. Pech, G. \& Leibel, R. (2006). Writing in solidarity: Steps toward an ethic of care for Journalism. Journal of Mass Media Ethics, 21, 141-155.

Critical Studies in Media Communication, Vol. 24, No. 5 (2007): pg. 429-445. DOI. This article is (C) Taylor \& Francis (Routledge) and permission has been granted for this version to appear in e-Publications@Marquette. Taylor \& Francis (Routledge) does not grant permission for this article to be further copied/distributed or hosted elsewhere without the express permission from Taylor \& Francis (Routledge). 
NOT THE PUBLISHED VERSION; this is the author's final, peer-reviewed manuscript. The published version may be accessed by following the link in the citation at the bottom of the page.

48. Polgreen, L. (2003, April 14). New Jersey family grieving daughter's death is lifted by son's rescue in Iraq. New York Times. Retrieved September 17, 2005 from http://www.nytimes.com

49. Purdum, T. \& Rutenberg, J. (2003, March 23). Reporters respond eagerly to Pentagon welcome mat. New York Times. Retrieved September 17, 2005 from http://www.nytimes.com

50. Rawls, J. (1971). A theory of justice. Cambridge, Ma: Harvard University Press.

51. Richtel, M. (2003, March 23). A nation at war: E-mail; for soldiers and their families, electronic links are vital. New York Times. Retrieved September 17, 2005 from http: www.nytimes.com

52. Ruddick, S. (1989). Maternal thinking: Toward a politics of peace. Boston: Beacon Press.

53. St. George, D. (2003, April 9). Product of ' 60 s, now the mother of a marine; Va. woman lives with the memories of then, the worries of now. Washington Post. Retrieved September 18, 2005 from http://www.washingtonpost.com

54. Scheper-Hughes, N. (1998). Maternal thinking and the politics of war. In L. Lorentzen \& J. Turpin (Eds.), Women's war reader (pp. 227-233). New York: New York University Press.

55. Strecker, E. (1946) Their mothers' sons: A psychiatrist examines an American problem. Philadelphia: J. B. Lippincott Company.

56. Steiner, L. (1989). Feminist theorizing and communication ethics. Communication, 12, 157-173.

57. Steiner, L. \& Okrusch, C. (2006). Care as a virtue for journalists. Journal of Mass Media Ethics, 21, 102-122.

58. Turpin, J. (1998). Many faces: Women confronting war. In L. Lorentzen \& J. Turpin (Eds.), Women's war reader (pp.3-18). New York: New York University Press.

59. Ware, S. (1997). Modern American women: A documentary history. New York: McGraw-Hill Companies, Inc.

Critical Studies in Media Communication, Vol. 24, No. 5 (2007): pg. 429-445. DOI. This article is @ Taylor \& Francis (Routledge) and permission has been granted for this version to appear in e-Publications@Marquette. Taylor \& Francis (Routledge) does not grant permission for this article to be further copied/distributed or hosted elsewhere without the express permission from Taylor \& Francis (Routledge). 
NOT THE PUBLISHED VERSION; this is the author's final, peer-reviewed manuscript. The published version may be accessed by following the link in the citation at the bottom of the page.

60. Wylie, P. (1955). Generation of Vipers. New York: Holt, Rinehart \& Winston.

61. Yardley, J. (2003, March 26). A nation at war: The prisoners' families; specialist Shoshana Johnson. New York Times. Retrieved September 17, 2005 from http://www.nytimes.com

62. Yoo, I. (2003, April 21). Military life strengthens bonds of love. USA Today. Retrieved on September 18, 2005 from http://www.usatoday.com

63. Zeigler, S. (1996). "She didn't raise her son to be a slacker: Motherhood, conscription, and the culture of the first world war." Feminist Studies 22(1), 6-40.

\section{Author Note}

This paper was originally presented at Wisconsin Women's Studies Conference, Black River Falls, WI, on April 21, 2006.

We thank Franziska U. Boerner, our research assistant, for her valuable assistance in the data collection and preliminary analysis.

\section{Footnotes}

${ }^{1}$ Women, including mothers, make up 15 percent of the active duty members of the U.S. military. Four times as many women have been deployed to Iraq and Afghanistan than were deployed during the Persian Golf War. Over 155,000 have been deployed since 2002. (retrieved March 23, 2007. http://www.military.com).

\section{About the Authors}

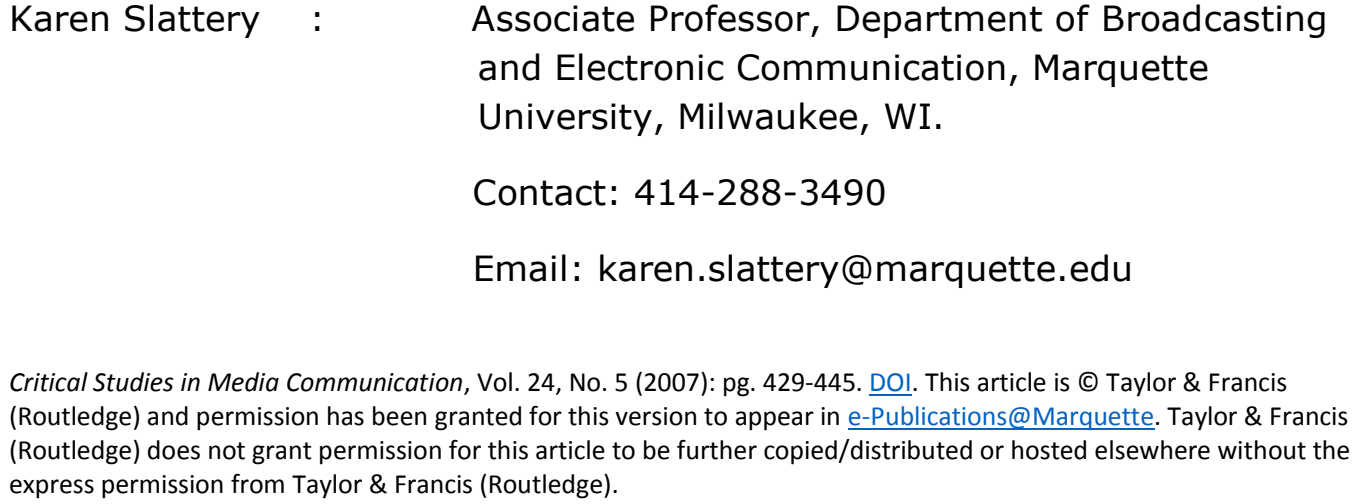

Critical Studies in Media Communication, Vol. 24, No. 5 (2007): pg. 429-445. DOI. This article is (C) Taylor \& Francis (Routledge) and permission has been granted for this version to appear in e-Publications@Marquette. Taylor \& Francis (Routledge) does not grant permission for this article to be further copied/distributed or hosted elsewhere without the express permission from Taylor \& Francis (Routledge). 
NOT THE PUBLISHED VERSION; this is the author's final, peer-reviewed manuscript. The published version may be accessed by following the link in the citation at the bottom of the page.

Ana C. Garner :

Associate Professor, College of Communication, Marquette University, Milwaukee, WI.

Contact: $414-288-7383$

Fax: 414-288-6494

Email: ana.garner@marquette.edu

Critical Studies in Media Communication, Vol. 24, No. 5 (2007): pg. 429-445. DOI. This article is (C) Taylor \& Francis (Routledge) and permission has been granted for this version to appear in e-Publications@Marquette. Taylor \& Francis (Routledge) does not grant permission for this article to be further copied/distributed or hosted elsewhere without the express permission from Taylor \& Francis (Routledge). 